\title{
Eczema das Mãos: Diferentes Abordagens
}

\author{
Francisco Menezes Brandão \\ Dermatologista, Hospital dos Lusíadas, Lisboa
}

O eczema ou dermatite das mãos é uma das entidades nosológicas mais frequentes na prática dermatológica diária. Pode corresponder a causas várias - dermatite de contacto irritativa ou alérgica, dermatite atópica, eczema disidrótico/ vesicular, dermatite de contacto proteica, eczema palmar hiperqueratósico - mas na maioria dos casos são situações multifactoriais - dermatite de contacto irritativa + alérgica, dermatite atópica + irritativa, dermatite atópica de padrão vesicular, etc.

Independentemente da causa ou causas subjacentes, o impacto que situações desta natureza têm no dia-a-dia destes pacientes nem sempre é correctamente avaliado nem valorizado pelo médico. As mãos são o nosso instrumento de trabalho, têm uma função de socialização, de aproximação e cumprimento, têm papel importante nas relações interpessoais e sexuais, pelo que quem sofre deste tipo de patologia pode, facilmente, sofrer uma sensação de rejeição. Esta, aliada ao sofrimento físico que o eczema das mãos ocasiona, pode afectar de modo relevante a qualidade de vida (QoL).

Neste número da Revista da Sociedade Portuguesa de Dermatologia e Venereologia esta vertente da QoL, relacionada com a gravidade da doença, é avaliada em artigo muito interessante, pela primeira vez abordada na literatura nacional. ' Em estudo prospectivo decorrido ao longo de um ano os autores demonstraram uma correlação positiva significativa entre a gravidade do eczema e a QoL, a qual também foi afectada pela idade dos doentes. Embora tenham limitado a avaliação aos doentes com dermatite de contacto alérgica e/ou irritativa, tudo leva a crer que nas outras manifestações clínicas do eczema das mãos as conclusões possam ser semelhantes.

Do mesmo modo que vem acontecendo, desde há anos, na psoríase e outras dermatoses, teremos que prestar mais atenção e valorizar mais esta vertente da QoL nos eczemas das mãos, e não limitarmos a nossa avaliação aos aspectos clínicos físicos da doença.

Ainda neste número da Revista outro importante artigo, relacionado com o eczema das mãos, chama-nos a atenção para aspecto para o qual nem sempre estaremos despertos - a potencial importância que nestes doentes podem ter as reacções imediatas, sejam do tipo urticária de contacto, sejam do tipo dermatite de contacto proteica, no desencadeamento ou na manutenção do eczema. ${ }^{2}$

De facto, se interrogarmos cuidadosamente os doentes, veremos que uma percentagem importante destes refere intolerância, com manifestações precoces, ao contacto com produtos diversos. Nem sempre estas queixas terão tradução real clínica, mas merecem sempre ser investigadas.

Embora se trate de estudo retrospectivo, com as inerentes limitações a estudos deste tipo, verificou-se que mais de $50 \%$ dos doentes investigados tinha testes de picada positivos relevantes, em especial para o látex e alimentos, mais de metade dos quais eram atópicos.

O mérito deste estudo advém de nos relembrar que os eczemas das mãos raramente são quadros clínicos unifactoriais, antes têm na sua génese causas endógenas e exógenas várias, as quais há que valorizar devidamente de modo a podermos controlar e tratar a dermatose.

\section{Hands Eczema: Different Perspectives}

Hand eczema or hand dermatitis is one of the most common dermatoses that we face in our daily practice. It may correspond to different causes - allergic or irritant contact dermatitis, atopic dermatitis, protein contact dermatitis, dyshidrotic/vesicular hand dermatitis, hyperkeratotic palmar dermatitis - but most of the times it is a multifactorial disease-allergic + irritant dermatitis, atopic + irritant or allergic dermatitis, etc.

Independently of the cause or causes, the impact that such dermatoses have in the daily activity and life of the patients
Correspondência: Francisco Menezes Brandão

E-mail: fmbrandao@sapo.pt

DOI: https://dx.doi.org/10.29021/spdv.76.2.932
Recebido/Received

01 Maio/March 2018

Aceite/Accepted

02 Maio/March 2018 


\section{Editorial}

is often ignored or forgotten by the clinician. The hands have a socialization function, of proximity and greeting, have an important function in inter personnel and sexual relationship. Therefore, people with hand dermatitis may easily suffer a rejection feeling that, together with physical suffering, may easily affect their quality of life (QoL) in a relevant way.

In the present number, the QoL related to the severity of the disease is assessed, for the first time in Portuguese dermatological literature, in a very interesting paper. ${ }^{1}$ In a one year prospective study the authors showed a significant positive correlation between the severity of the hand eczema, age of the patients and QoL. Although the study was limited to patients with allergic and/or irritant contact dermatitis, we may assume that in others types of hand dermatitis the conclusions must be quite similar.

For several years, QoL in other dermatological conditions, such as psoriasis and atopic dermatitis, has captured the attention of the dermatologists as a very important issue in the evaluation of disease severity. From now on we must pay attention to this aspect in patients with of hand eczema, not limiting our evaluation to the mere physical aspects of the disease.

Also in this number, another interesting paper related with hand eczema, calls our attention for another point, which has not been usually assessed in clinical practice - the importance of immediate reactions, be it contact urticaria or protein contact dermatitis, in the development or maintenance of the eczema. ${ }^{2}$

In fact, if we do thoroughly ask the patients, a high percentage will report immediate intolerance to the handling of several products, with either pruritus only or other skin manifestations.

Although this is a retrospective study, with the inherent limitations, over $50 \%$ of the investigated patients had relevant positive prick tests, especially to latex and food products, most of them were atopic.

The interesting aspect in this study is to point out that most of hand eczemas are not due to a single factor, usually being due to a mix of endogenous and exogenous causes. The evaluation of the relative importance of each of them is essential to the control and treatment of the eczema.

\section{REFERÊNCIAS}

1. tos RP Igreja L, Resende C, Pereira T, Brito C. Hand eczema: Quality of Life and disease severity in na outpatient portuguese population. Rev Soc Port Dermatol Venereol. 2018; 76: 135-40.

2. Azevedo J, Regateiro F, Gouveia M, Ramos L, Gonçalo $M$. Testes imediatos em doentes com eczema das mãos. Rev Soc Port Dermatol Venereol. 2018; 78: 141-8. 